\title{
Influence of brine concentration and temperature on composition, microstructure, and yield of feta cheese
}

\author{
D. J. McMahon, ${ }^{* 1}$ M. M. Motawee, $†$ and W. R. McManus* \\ *Western Dairy Center, Utah State University, Logan 84322 \\ †National Organization for Drug Control and Research, Cairo, Egypt
}

\begin{abstract}
The protein matrix of cheese undergoes changes immediately following cheesemaking in response to salting and cooling. Normally, such changes are limited by the amount of water entrapped in the cheese at the time of block formation but for brined cheeses such as feta cheese brine acts as a reservoir of additional water. Our objective was to determine the extent to which the protein matrix of cheese expands or contracts as a function of salt concentration and temperature, and whether such changes are reversible. Blocks of feta cheese made with overnight fermentation at 20 and $31^{\circ} \mathrm{C}$ yielded cheese of pH 4.92 and $\mathrm{pH} 4.83$ with 50.8 and $48.9 \mathrm{~g} / 100$ $\mathrm{g}$ of moisture, respectively. These cheeses were then cut into 100-g pieces and placed in plastic bags containing $100 \mathrm{~g}$ of whey brine solutions of $6.5,8.0$, and $9.5 \%$ salt, and stored at $3,6,10$, and $22^{\circ} \mathrm{C}$ for $10 \mathrm{~d}$. After brining, cheese and whey were reweighed, whey volume measured, and cheese salt, moisture, and $\mathrm{pH}$ determined. A second set of cheeses were similarly placed in brine $(\mathrm{n}=9)$ and stored for $10 \mathrm{~d}$ at $3^{\circ} \mathrm{C}$, followed by $10 \mathrm{~d}$ at $22^{\circ} \mathrm{C}$, followed by $10 \mathrm{~d}$ at $3{ }^{\circ} \mathrm{C}$, or the complementary treatments starting at $22^{\circ} \mathrm{C}$. Cheese weight and whey volume $(\mathrm{n}=3)$ were measured at 10,20 , and $30 \mathrm{~d}$ of brining. Cheese structure was examined using laser scanning confocal microscopy. Brining temperature had the greatest influence on cheese composition (except for salt content), cheese weight, and cheese volume. Saltin-moisture content of the cheeses approached expected levels based on brine concentration and ratio of brine to cheese (i.e., 4.6, 5.7 and $6.7 \%$ ). Brining at $3{ }^{\circ} \mathrm{C}$ increased cheese moisture, especially for cheese with an initial $\mathrm{pH}$ of 4.92 , producing cheese with moisture up to 58 $\mathrm{g} / 100 \mathrm{~g}$. Cheese weight increased after brining at 3, 6, or $10^{\circ} \mathrm{C}$. Cold storage also prevented further fermentation and the $\mathrm{pH}$ remained constant, whereas at $22^{\circ} \mathrm{C}$ the $\mathrm{pH}$ dropped as low as $\mathrm{pH}$ 4.1. At $3^{\circ} \mathrm{C}$, the cheese matrix expanded (20 to $30 \%$ ), whereas at $22^{\circ} \mathrm{C}$ there
\end{abstract}

Received March 4, 2009

Accepted May 5, 2009

${ }^{1}$ Corresponding author: donald.mcmahon@usu.edu was a contraction and a 13 to $18 \mathrm{~g} / 100 \mathrm{~g}$ loss in weight. Expansion of the protein matrix at $3{ }^{\circ} \mathrm{C}$ was reversed by changing to $22^{\circ} \mathrm{C}$. However, contraction of the protein matrix was not reversed by changing to $3^{\circ} \mathrm{C}$, and the cheese volume remained less than what it was initially. Key words: cheese, brining, structure, yield

\section{INTRODUCTION}

Feta cheese is a pickled cheese traditionally made from sheep's milk that has its origins in Greece where its annual consumption is still the highest in the world at $12 \mathrm{~kg} /$ person (Anifantakis and Moatsou, 2006). Its usage spread with the Greek diaspora to other countries (such as Australia, the United States, and Canada), where feta became a generic term for white pickled cheese made from cow's milk. There are many different types of pickled cheeses that are preserved or stored in brine, and their names vary from one region to another. In the 1980s and 1990s, cow's milk feta cheese was the most significant type of pickled cheese exported and marketed in the world (Tamime et al., 1996). Global production of feta-type cheeses is currently about $1 \times$ $10^{9} \mathrm{~kg} / \mathrm{yr}$, which is about $7 \%$ of total global cheese production (Chr. Hansen, 2009). Feta is a major cheese type in the Asia-Pacific-Middle East-Africa region and accounts for one-third of total cheese produced in this region. During 2008, there was a large increase in new feta cheese products, especially in Africa, the United States, and Greece (Chr. Hansen, 2009). Since 2002, the name "Feta" has a Product of Designation of Origin registration such that in the European Union it can only be applied to cheeses manufactured in certain geographical areas of Greece using sheep's or sheep/ goat's milk (European Union, 2002; Anifantakis and Moatsou, 2006).

In traditional manufacture of feta cheese, after initial whey drainage and block formation, cheese blocks are dry salted over several days with the cheese held at 16 to $18^{\circ} \mathrm{C}$ and exposed to air so that a slimy growth of bacteria and yeast forms on the cheese surface (Anifantakis and Moatsou, 2006). This is later washed off before final packaging into a $7 \%$ brine solution, but 
contributes to cheese maturation and flavor development during further storage at 16 to $18^{\circ} \mathrm{C}$ for about 2 wk before being transferred into cold storage at 3 to $4^{\circ} \mathrm{C}$. A milder flavor feta cheese can be made by reducing or eliminating the dry-salting time and immersing the cheese in brine after overnight fermentation and gravity drainage of the curd blocks. Such early brining interrupts the development of the secondary microflora (Bintsis, 2006).

There are variable ways in which pickled cheeses are salted, and brining gives faster rates of salt absorption, a more even distribution of salt in the cheese, and produces cheeses with higher retention of moisture and hence higher yields (Bines and Holmes, 1994), which, along with the milder flavor, is an incentive for its use in large production facilities (Bintsis, 2006). Traditionally, a crude rennet obtained from abomasa of lambs and kids was used as the coagulant for making feta cheese, which contributed to flavor development by lipase and pregastric esterases (Anifantakis and Moatsou, 2006). These enzymes are not present in modern commercial rennets, so lipases are added to the milk before renneting to provide the aroma and peppery taste characteristic of feta cheese.

In general, salting promotes syneresis of whey from the curd, reducing the moisture content of the cheese, although this can be influenced by other intrinsic and extrinsic factors such as the calcium content of the cheese (Paulson et al., 1998) and temperature (Turhan and Kaletunç, 1992). A small amount of salt $(<0.8 \%)$ can cause a physical change in the proteins in cheese by increasing their water solubility and hydration as described by Paulson et al. (1998). Calcium concentrations of 0.5 to $0.6 \%$ in brine are needed to prevent leaching of calcium from the cheese surface and its increased hydration resulting in "soft rind" defects (Geurts et al., 1972). Increasing the salt concentration of brine will give faster salt diffusion and lower final cheese moisture (Prasad and Alvarez, 1999) but at very high levels, such as in saturated brine, "salting-out" can occur, causing a contraction of the protein matrix and reduced salt diffusion (Melilli et al., 2003).

The objective of our research was first to investigate cheese weight and volume during storage of feta cheese in brine at warm and cold temperatures and to determine their reversibility, and then to relate these changes to changes in the cheese microstructure.

\section{MATERIALS AND METHODS}

\section{Materials}

The starter culture used was Choozit Feta A (Danisco USA Inc., New Century, KS), which consisted of a lyo- philized blend of various strains of Lactococcus lactis, Lactobacillus species, and Streptococcus thermophilus; Holdbac LC (Danisco USA Inc.), a Lactobacillus rhamnosus culture, was used as an adjunct. Kid goat lipase powder (\#71444) was obtained from Chr. Hansen Inc. (Milwaukee, WI) and double-strength $(\sim 650$ international milk clotting units/mL) chymosin rennet (Maxiren) was obtained from DSM Food Specialties USA Inc. (Eagleville, PA). Cow's milk was obtained from the Utah State University's Caine Dairy Research and Teaching Center (Wellsville, UT).

\section{Cheesemaking}

Milk was pasteurized at $73^{\circ} \mathrm{C}$ for $15 \mathrm{~s}$, and $136 \mathrm{~kg}$ was poured into an open cheese vat in the Gary H. Richardson Dairy Products Laboratory at Utah State University. Milk was warmed to $35^{\circ} \mathrm{C}$, and $4 \mathrm{~g}$ of starter culture and $1 \mathrm{~g}$ of adjunct culture were added and allowed to ripen for $60 \mathrm{~min}$. Ten grams of lipase and 12 $\mathrm{mL}$ of rennet (57 international milk clotting units $/ \mathrm{kg}$ of milk) were added, the curd was cut after 30 min using wire knives (16 $\mathrm{mm}$ spacing), and then stirred after $15 \mathrm{~min}$ of healing. About one-third of the whey was removed after $30 \mathrm{~min}$ and then curd and whey were transferred into 4 perforated rectangular stainless steel molds and the curd allowed to mat together and press under its own weight. The molds were turned 4 times at 20-min intervals and then 2 forms were transferred to a warm room $\left(31^{\circ} \mathrm{C}\right)$ with the other 2 remaining at room temperature $\left(\sim 20^{\circ} \mathrm{C}\right)$ for overnight fermentation and continued whey drainage. The next day, the cheese blocks were removed from the forms and cut into 100\pm 1 -g pieces in preparation for brining.

\section{Brining}

Whey that was removed during cheese making was used to prepare brine solutions of 6.5, 8.0, and 9.5\% (wt/wt) salt by adding $\mathrm{NaCl}$, and then adjusting the $\mathrm{pH}$ of each to 4.7 by adding vinegar. Each $100-\mathrm{g}$ piece of cheese was placed into a reclosable plastic bag (Hefty One Zip Quart Freezer bag; Pactiv Corp., Lake Forest, IL) in triplicate and $100 \pm 1 \mathrm{~g}$ of brine added. Air was expelled from the bag, and the bag closed and stored at its designated temperature. One set of cheeses was stored at $3,6,10$, or $22^{\circ} \mathrm{C}$ for $10 \mathrm{~d}$ and then analyzed. A second set of cheeses (from cheese fermented at $31^{\circ} \mathrm{C}$ ) underwent brining with the temperature alternating between cold and warm storage starting with $10 \mathrm{~d}$ at $3^{\circ} \mathrm{C}$, followed by $10 \mathrm{~d}$ at $22^{\circ} \mathrm{C}$, then $10 \mathrm{~d}$ at $3^{\circ} \mathrm{C}$. Brining of the third set of cheeses started with warm storage for $10 \mathrm{~d}$ at $22^{\circ} \mathrm{C}$, followed by $10 \mathrm{~d}$ at $3^{\circ} \mathrm{C}$, and then a final $10 \mathrm{~d}$ at $22^{\circ} \mathrm{C}$. 


\section{Cheese Analysis}

Moisture content was determined in triplicate by weight loss using a microwave oven (CEM Corp., Indian Trail, NC) at $70 \%$ power with an endpoint setting of $<0.4 \mathrm{mg}$ of weight change over $2 \mathrm{~s}$. Fat content was determined in duplicate using a modified Babcock method (Richardson, 1985). Salt was measured by homogenizing grated cheese with distilled water for 4 min at 260 rpm in a Stomacher 400 (Seward, London, UK). The slurry was filtered through a Whatman \#1 filter paper, and the filtrate was analyzed for sodium chloride using a chloride analyzer (model 926, Corning, Medfield, MA). Salt-in-moisture (S/M) content was calculated as the percentage (by weight) of salt in the cheese based on combined moisture plus salt content. The $\mathrm{pH}$ was measured using a glass electrode after stomaching $20 \mathrm{~g}$ of grated cheese with $10 \mathrm{~g}$ of distilled water for $1 \mathrm{~min}$ at $260 \mathrm{rpm}$. After brining, the weight of each cheese block, and residual brine solution was measured, as well as brine volume. The change in cheese volume was considered equal to the change in brine volume, using initial densities of $1.02,1.03,1.05$, and $1.07 \mathrm{~g} / \mathrm{mL}$ for the cheese, $6.5,8.0$, and $9.5 \%$ brines, respectively.

\section{Microstructure}

Cheese samples at 3 and $22^{\circ} \mathrm{C}$ were prepared for examination by laser scanning confocal microscopy (LSCM) based on the method of McManus et al. (2009) so that their structure did not change during sample staining and viewing by LSCM. Small pieces of cheese about $8 \times 8 \times 2 \mathrm{~mm}$ were immersed in $0.10 \mathrm{~g} / \mathrm{mL}$ osmium tetroxide (Ted Pella, Redding, CA) in whey, and protein and fat fixation performed by placing the sample in a Pelco 3470 microwave system (Ted Pella) at power 6 for $20 \mathrm{~min}$ and then holding the sample in the fixative overnight. The fixed cheese sample was rinsed 3 times in water (distilled deionized) and then soaked in $0.20 \mathrm{~g} / \mathrm{mL}$ Nile Red (Sigma-Aldrich Inc., St. Louis, $\mathrm{MO}$ ) in dimethylsulfoxide (Sigma-Aldrich Inc.) for 5 min to stain for fat. It was then rinsed twice in water, and stained with $0.050 \mathrm{~g} / \mathrm{mL}$ fluorescein isothiocyanate (FITC; Sigma-Aldrich Inc.) in acetone:water (1:1) solution to stain for protein. The stained sample was mounted on standard microscope slides with glycerin jelly, coverslipped, and placed on an inverted microscope (model MRC 23, BioRad, Hercules, CA) with a $\mathrm{Kr} / \mathrm{Ar}$ laser, exciting FITC at $488 \mathrm{~nm}$ and Nile Red at $568 \mathrm{~nm}$. Fluorescent emissions were from 488 to 650 $\mathrm{nm}$ and from 550 to $750 \mathrm{~nm}$ for FTIC and Nile Red, respectively, and captured sequentially using exclusion filters of 512 to $532 \mathrm{~nm}$, and $\geq 585 \mathrm{~nm}$. Images were false-colored with fat as orange and protein as light green.

\section{Experimental Design}

Difference in composition of cheese after fermentation (i.e., before brining) were analyzed using the 2-tailed Student's $t$-test function in Excel 2008 (Microsoft Corp., Seattle, WA). Cheese composition and cheese and brine weight and volume after brining for $10 \mathrm{~d}$ were analyzed as a 2-way factorial of temperature and concentration with 3 replicates. The experiments in which cheese was brined at alternating temperatures for periods of $10 \mathrm{~d}$ were analyzed separately as 2 -way factorials of brine concentration and storage time with 3 replicates. Analysis of variance was performed after log-transformation to normalize the data using PROC GLM in SAS (version 9.1, SAS Institute, Cary, NC) with REGW multiple range test and Tukey least squares means.

\section{RESULTS AND DISCUSSION}

\section{Cheese Composition Before Brining}

Allowing the cheese blocks to ferment overnight at different temperatures, $20^{\circ} \mathrm{C}$ (overnight room temperature) and $31^{\circ} \mathrm{C}$, produced cheese with different moisture and $\mathrm{pH}$. At the lower temperature, fermentation by the starter culture was retarded and after $20 \mathrm{~h}$ the cheese had only reached $\mathrm{pH} 4.92$ compared with $\mathrm{pH} 4.83$ when stored at $31^{\circ} \mathrm{C}(P=0.002)$. There was also a difference in moisture, with more syneresis occurring at the higher temperature, resulting in significantly $(P<0.001)$ lower moisture contents; that is, 48.9 and $50.8 \mathrm{~g} / 100$ $\mathrm{g}$ for cheeses fermented at 31 and $20^{\circ} \mathrm{C}$ respectively. Salt contents of the cheeses were the same $(0.11 \mathrm{~g} / 100$ $\mathrm{g}$ ) and there was a slight difference in fat content with cheese fermented at the higher temperature having a slightly higher fat level of $51.9 \mathrm{~g} / 100 \mathrm{~g}$ compared with $50.9 \mathrm{~g} / 100 \mathrm{~g}$ of fat on a dry basis (FDB; $P<0.001$ ). Although both cheeses were made from the same vat of milk, the increased FDB probably resulted from higher losses of nonfat solids (such as lactose, whey proteins, and minerals) with the higher syneresis that occurred during overnight fermentation at $31^{\circ} \mathrm{C}$.

\section{Cheese Composition After Brining}

Moisture. As shown in Table 1, the final moisture content of the cheese was influenced by the temperature of overnight fermentation. Those cheeses that were fermented at $31^{\circ} \mathrm{C}$, in general, had lower moisture contents after brining compared with those fermented at $20^{\circ} \mathrm{C}$. This was dependent on both brining temperature and brine salt concentration, with both factors and their interaction having significant affects on moisture $(P<$ 0.001). The average differences in moisture were 7.4 , 
Table 1. Mean $\mathrm{pH}$, moisture, and salt content of feta cheeses after $10-\mathrm{d}$ brining in $6.5,8.0$, and $9.5 \%$ (wt/wt) salt brine at $3,6,10$, and $22^{\circ} \mathrm{C}$

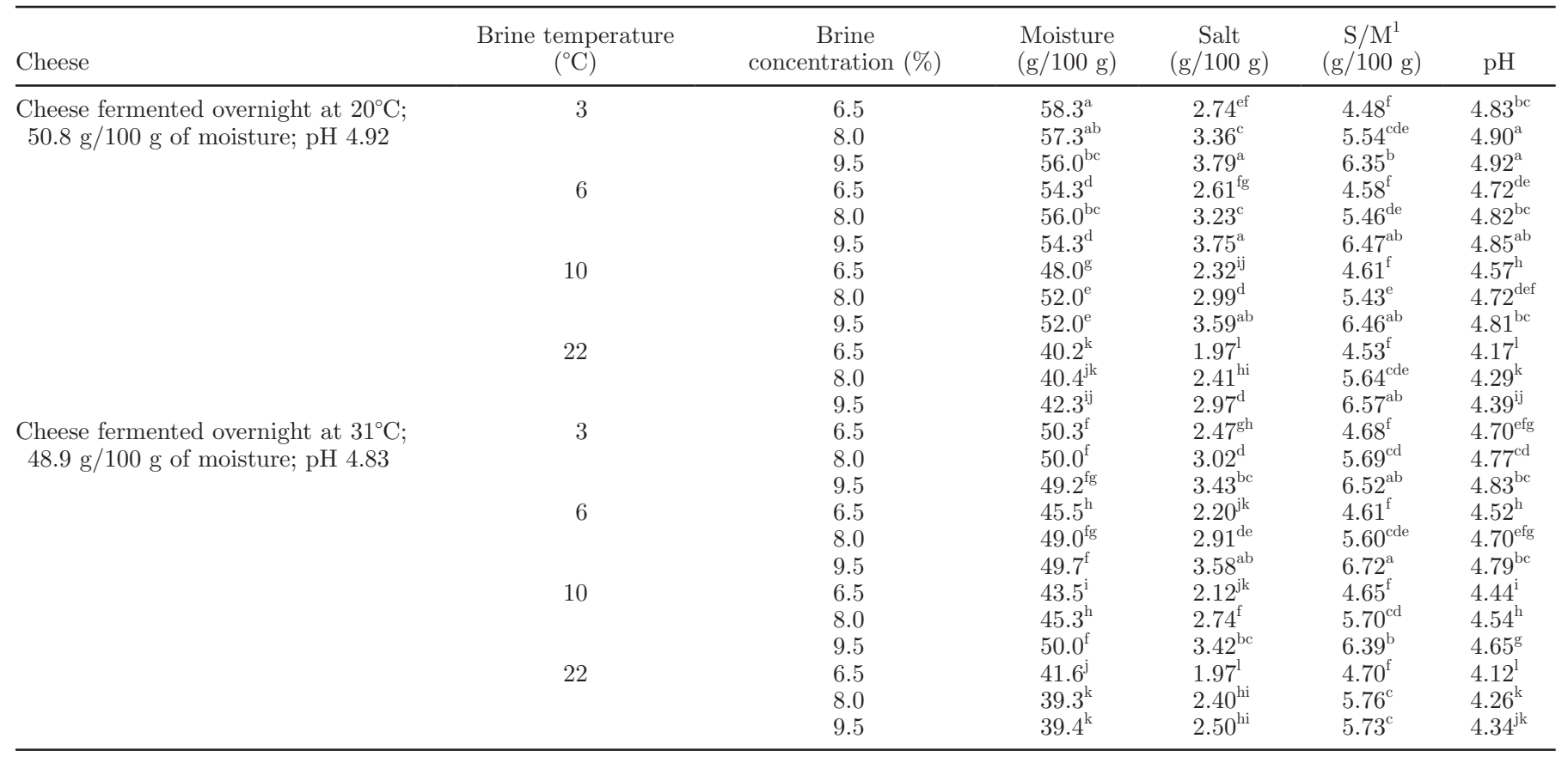

${ }^{\mathrm{a}-\mathrm{l}}$ Means within a column with a common superscript letter were not significantly different $(\alpha=0.05)$.

${ }^{1}$ Salt-in-moisture $=$ salt $/($ salt + moisture $) \times 100$.

6.8, 4.4, and $0.9 \mathrm{~g} / 100 \mathrm{~g}$ lower for cheeses brined at 3, 6,10 , and $22^{\circ} \mathrm{C}$, respectively. Whether this was a function of the initial lower moisture or $\mathrm{pH}$ could not be determined, although lower moisture loss is normally associated with a lower cheese pH (Guinee, 2004). Cheese with increased syneresis during fermentation (and hence lower moisture) would be expected to have allowed more crosslinking to occur between protein strands within the protein matrix. Such crosslinking would then act to restrict the level of changes taking place during brining. Having a lower $\mathrm{pH}$ could also play a role although it has been shown that below $\mathrm{pH} 5.0$, protein solubility becomes the controlling factor for determining the physical properties of the cheese protein matrix (Pastorino et al., 2003).

Cheese texture mirrored moisture content and was more dependent on temperature during brining than salt content. Cheeses brined at $3^{\circ} \mathrm{C}$ were the softest, especially those from the $20^{\circ} \mathrm{C}$ fermentation that had the higher initial $\mathrm{pH}$ and moisture contents. Such cheeses brined at $3^{\circ} \mathrm{C}$ had final average moisture contents of $57.2 \mathrm{~g} / 100 \mathrm{~g}$ and were very soft. Cheese brined at $6^{\circ} \mathrm{C}$ (with $54.9 \mathrm{~g} / 100 \mathrm{~g}$ average moisture) was considered soft and comparable to what would be expected for a relatively young, white brined cheese such as feta or Domiati cheese.

Moisture uptake from the brine during cold storage is typical of white-brined cheeses (Alichanidis et al., 1981;
Pappas et al., 1996). Cheeses brined at $10^{\circ} \mathrm{C}(50.7 \mathrm{~g} / 100$ $\mathrm{g}$ average moisture) were firmer than those brined at $6^{\circ} \mathrm{C}$, whereas those brined at $22^{\circ} \mathrm{C}(41.0 \mathrm{~g} / 100 \mathrm{~g}$ average moisture) were quite hard and were more typical of white-brined cheese that had been aged for a year or more. There was a slight effect of salt concentration of the brine on final moisture of the cheese although this varied based on storage temperature and initial $\mathrm{pH}$ and moisture of the cheese (Table 1).

In comparison, the average gross composition of feta cheese obtained from different retail outlets in Greece was $52.9 \mathrm{~g} / 100 \mathrm{~g}$ of moisture, $55.6 \mathrm{~g} / 100 \mathrm{~g}$ of FDB, 16.7 $\mathrm{g} / 100 \mathrm{~g}$ of protein, and $5.27 \mathrm{~g} / 100 \mathrm{~g}$ of S/M (Anifantakis and Moatsou, 2006). In the United States, there are no standards of identity for feta cheese and it can have a broad range of composition, with moisture being as high as 55 to $60 \mathrm{~g} / 100 \mathrm{~g}$ and FDB $<40 \mathrm{~g} / 100 \mathrm{~g}$ (M. E. Johnson, Wisconsin Center for Dairy Research, Madison; personal communication). This is a reflection of how companies standardize their milk composition and optimization of their cheesemaking process on an economic basis.

$\boldsymbol{p H}$. After $10 \mathrm{~d}$ of brining, cheese $\mathrm{pH}$ had decreased depending on brine concentration, temperature, and their interaction $(P<0.001)$ as shown in Table 1. Lactic acid bacteria (either starter or nonstarter bacteria) grow at a fast rate during the fermentation and early stages of cheese maturation (Anifantakis and Moatsou, 2006), 
provided the temperature remains sufficiently high. When cheese was brined at $3^{\circ} \mathrm{C}$, there was very little decrease in $\mathrm{pH}$ (average of 0.05 units), whereas a large decrease in $\mathrm{pH}$ (average of 0.61 units) occurred when the cheese was stored at $22^{\circ} \mathrm{C}$ with the cheeses reaching as low as $\mathrm{pH} 4.1$ after $10 \mathrm{~d}$ after brining. Cheeses brined at 6 and $10^{\circ} \mathrm{C}$ had intermediate $\mathrm{pH}$ decreases of 0.14 and 0.25 units, respectively. This corresponds with the known interruption in biochemical activity of feta cheese during maturation (and consequent milder flavor) that occurs when feta cheese is placed in brine without the week-long traditional dry salting period at 16 to $18^{\circ} \mathrm{C}$ (Bintsis, 2006).

Lower salt concentrations also allowed more generation of lactic acid and larger $\mathrm{pH}$ decreases during brining. However, with the limited range of salt concentrations used in this experiment, the effect of salt was not as great as the effect of temperature. After $10 \mathrm{~d}$ of brining, the average $\mathrm{pH}$ decrease was $0.27,0.25$, and 0.18 units for cheeses brined in $6.5,8.0$, and $9.5 \%$ salt brines. There was little difference between use of the 6.5 and $8.0 \%$ brines, but significant retardation of acid development occurred in the $9.5 \%$ brine.

Salt. During brining, salt is absorbed into the cheeses with a concomitant decrease in concentration of salt in the brine. This net movement of $\mathrm{Na}^{+}$and $\mathrm{Cl}^{-}$ions occurs because of osmotic pressure differences between cheese and brine (Guinee and Fox, 2004). Brine used for these experiments was prepared from whey obtained during cheesemaking; thus, minerals other than $\mathrm{Na}^{+}$ and $\mathrm{Cl}^{-}$would have been similar in both cheese and brine and so no movement of minerals ions such as $\mathrm{Ca}^{++}$and $\mathrm{H}_{2} \mathrm{PO}_{4}^{-}$was expected to occur during brining. The observed softening of the cheeses when brined at low temperature was therefore considered to result from the decreased strength of protein interactions allowing an infusion of moisture into cheese rather than from having too little calcium in the brine.

Salt concentration in the brined cheeses was influenced by salt content $(P<0.001)$ and temperature of the brine $(P<0.001)$ as shown in Table 1 . For cheeses fermented at $31^{\circ} \mathrm{C}$, there was not a significant interaction between temperature and salt content of the brine $(P=0.35)$ but there was for the cheese fermented at $20^{\circ} \mathrm{C}(P<0.001)$. When pooled over all temperatures for both warm and cool fermentation conditions, average salt content of cheeses after $10 \mathrm{~d}$ in $6.5,8.0$, and $9.5 \%$ brines were $2.30,2.88$, and $3.37 \mathrm{~g} / 100 \mathrm{~g}$, respectively. The cheeses made using the warmer fermentation temperature were an average $0.26 \mathrm{~g} / 100 \mathrm{~g}$ lower in salt, which was attributed to these cheeses being lower in moisture and therefore having less aqueous phase into which salt could diffuse from the brine.
Taking into account initial cheese moisture (48.9 and $50.8 \mathrm{~g} / 100 \mathrm{~g})$ and salt $(0.11 \mathrm{~g} / 100 \mathrm{~g})$ contents, and that equal weights $(100 \mathrm{~g})$ of cheese and brine were mixed together (and assuming the salt content throughout all the water phase was equalized after $10 \mathrm{~d}$ of brining), the overall $\mathrm{S} / \mathrm{M}$ content of the cheese/brine system would have been, on average, 4.6, 5.7, and $6.7 \mathrm{~g} / 100 \mathrm{~g}$ for the $6.5,8.0$, and $9.5 \%$ brines, respectively. On average, these were the $\mathrm{S} / \mathrm{M}$ levels measured in the cheeses after $10 \mathrm{~d}$ of brining. Mean cheese S/M for cheeses brined in the $6.5,8.0$, and $9.5 \%$ brines were $4.60,5.60$, and $6.40 \mathrm{~g} / 100 \mathrm{~g}$, respectively. As salt concentration increased there was slightly less salt absorbed into the cheese than theoretically expected, although at 9.5\% salt brine concentration, the final $\mathrm{S} / \mathrm{M}$ in the cheese was still only $0.3 \mathrm{~g} / 100 \mathrm{~g}$ less than predicted. Thus, a desired $\mathrm{S} / \mathrm{M}$ level in feta cheese can be easily obtained by controlling the cheese weight to brine weight ratio and taking into account the moisture content of cheese before brining and salt content of the brine. In our experiment, the brine to cheese ratio was $1: 1$, which, for the $9.5 \%$ brine, produced a cheese with $\mathrm{S} / \mathrm{M}$ similar to the $6.27 \mathrm{~g} / 100 \mathrm{~g}$ reported for feta cheese by Abd El-Salam and Alichanidis (2004). For salt uptake not to be influenced by the amount of cheese being brined, the brine to cheese ratio needs to be increased to $5: 1$ (Bintsis, 2006).

Temperature had only a slight effect on final S/M contents and this was only evident in cheeses fermented at $20^{\circ} \mathrm{C}(P=0.03)$ and not in cheeses fermented at $31^{\circ} \mathrm{C}(P=0.76)$. There was no significant interaction between salt concentration and temperature $(P=0.87)$ and when averaged over all salt concentrations, mean $\mathrm{S} / \mathrm{M}$ for each temperature was within the range of 5.53 $\pm 0.05 \mathrm{~g} / 100 \mathrm{~g}$. Usually increasing brining temperature increases both the diffusion rate of salt into cheese and the amount of salt absorbed (Turhan and Kaletunç, 1992; Prasad and Alvarez, 1999). This would only be apparent with shorter brining times and our brine concentrations were much lower than the $>20 \%$ salt solutions required to produce salting-out of the proteins and loss of porosity at the cheese surface.

Lactococcus starter cultures are typically inhibited in growth, and acid production slows down as S/M levels increase (especially at $\mathrm{S} / \mathrm{M}>5.0 \mathrm{~g} / 100 \mathrm{~g}$ ), but lactobacilli nonstarter bacteria found in cheese are usually more salt tolerant and require an $\mathrm{S} / \mathrm{M}>6 \mathrm{~g} / 100 \mathrm{~g}$ to retard their activity (Guinee and Fox, 2004). Thus, the observed average $\mathrm{pH}$ decreases of $0.37,0.25$, and 0.18 units for cheeses brined to S/M levels of 4.6, 5.6, and 6.4 $\mathrm{g} / 100 \mathrm{~g}$, respectively, correspond to extent of expected inhibition of bacterial activity with salt concentration. A combination of high salt $(9.5 \%$ brine, $6.7 \mathrm{~g} / 100 \mathrm{~g}$ 
Table 2. Change in cheese weight and volume after 10-d brining of $100 \mathrm{~g}$ of cheese in $100 \mathrm{~g}$ of $6.5,8.0$, or 9.5\% (wt/wt) salt brine at 3, 6, 10, and $22^{\circ} \mathrm{C}$

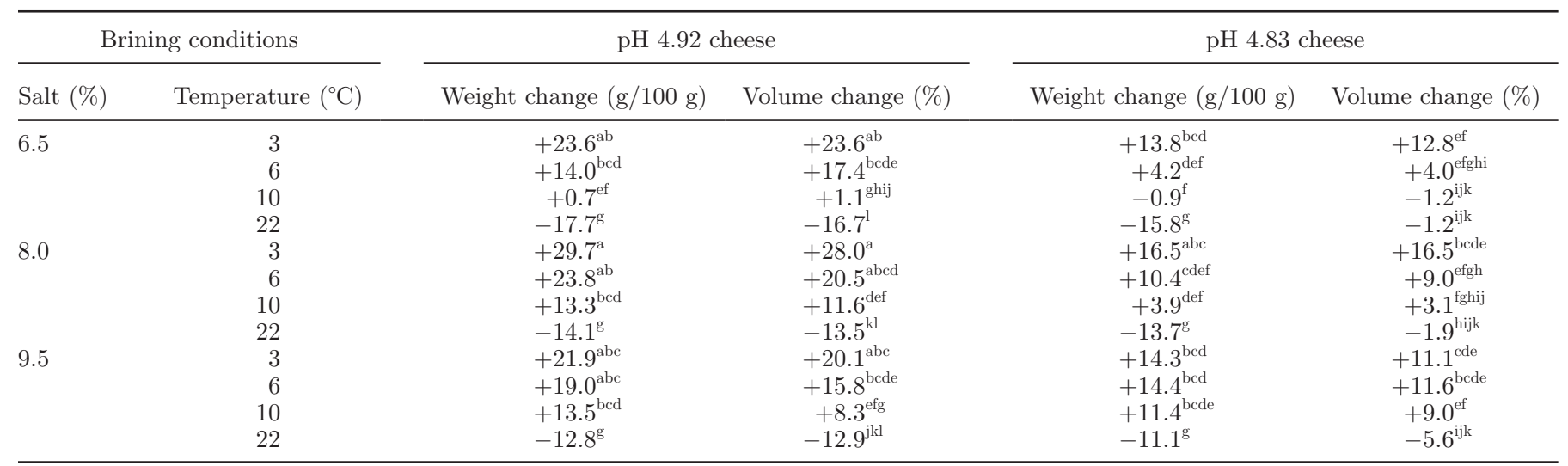

${ }^{\mathrm{a}-\mathrm{l}}$ Means within weight or volume columns with a common superscript letter were not significantly different $(\alpha=0.05)$.

$\mathrm{S} / \mathrm{M})$ and low temperature $\left(3^{\circ} \mathrm{C}\right)$ was sufficient to completely inhibit acid development with zero change in $\mathrm{pH}$ occurring during brining. At the other extreme, with low salt $(6.5 \%$ brine, $4.6 \mathrm{~g} / 100 \mathrm{~g} \mathrm{~S} / \mathrm{M})$ and high temperature $\left(22^{\circ} \mathrm{C}\right)$, there was little inhibition of bacterial growth and a 0.73 -unit drop in $\mathrm{pH}$ occurred.

\section{Cheese Yield}

Both brine temperature $(P<0.001)$ and salt concentration $(P<0.001)$ and the temperature $\times$ concentration interaction $(P=0.0004)$ influenced changes in cheese weight during brining (Table 2). Salt concentration in the range used for this study had a minor effect with those cheeses being stored in 8.0 or $9.5 \%$ salt brine having a mean $5 \mathrm{~g} / 100 \mathrm{~g}$ additional increase in weight compared with those brined in $6.5 \%$ salt brine. The cheeses that started out with lower moisture contents (i.e., those subjected to warm fermentation) also had about $5 \mathrm{~g} / 100 \mathrm{~g}$ less change in weight.

The dominant factor influencing cheese weight was the temperature at which cheeses were brined, with weight being gained at lower temperatures and weight lost when cheese was brined at $22^{\circ} \mathrm{C}$. The lower the temperature, the greater the weight gain with mean changes in weight of $+20.0,+14.3$, and $+7.0 \mathrm{~g} / 100$ g occurring at 3,6 , and $10^{\circ} \mathrm{C}$, respectively, compared with a mean weight change of $-14.2 \mathrm{~g} / 100 \mathrm{~g}$ when the cheese was brined at $22^{\circ} \mathrm{C}$. Therefore, if a cheese is sold in a brine solution, the temperature at which it is expected to be stored needs to taken into consideration when determining the net weight of cheese.

Part of the weight increase results from absorption of salt during brining, but most of the weight increase occurs because of absorption of brine into the cheese and a subsequent increase in volume (Table 2). The lower the temperature and salt concentration of the brine, the greater the volume of brine absorbed into the cheese $(P$ $<0.001, P=0.001$, respectively). For cheeses fermented overnight at $20^{\circ} \mathrm{C}$ (with $\mathrm{pH}$ of 4.92), the mean absorption of brine into the cheese was $9.35,14.7$, and $21.6 \mathrm{~mL}$ for cheese brined at 10,6 , and $3^{\circ} \mathrm{C}$, respectively. When brined at $22^{\circ} \mathrm{C}$, there was a mean transfer of serum into the brine of $11.3 \mathrm{~mL} / 100 \mathrm{~g}$ of cheese. The cheeses fermented at $31^{\circ} \mathrm{C}$ (with $\mathrm{pH}$ of 4.83 ) demonstrated less weight change but with the same trend with $3.7,8.4$, and $13.8 \mathrm{~mL}$ of the brine being absorbed into $100 \mathrm{~g}$ of cheese at 10,6 , and $3^{\circ} \mathrm{C}$, respectively, and a loss of 3.0 $\mathrm{mL} / 100 \mathrm{~g}$ of cheese at $22^{\circ} \mathrm{C}$.

Brine concentration had less influence on volume of brine absorbed into the cheese than temperature, with a general trend of slightly more brine absorption as brine concentration increased from 6.5 to $9.5 \%$. These changes were attributed to a decrease in protein-protein interactions as temperature is lowered and salt concentration increased. Paulson et al. (1998) showed that when cheese curd is salted there is an increase in the water-holding capacity of the cheese protein matrix, so that absorption of water into cheese would be expected when cheese is brined. Pastorino et al. (2002) reported that heating cheese promotes hydrophobic interactions between proteins as $\beta$-casein and calcium become less soluble, resulting in increased protein aggregation as shown by Metzger et al. (2000).

At $3^{\circ} \mathrm{C}$, hydrophobic interactions are minimized, whereas at $22^{\circ} \mathrm{C}$ they are of considerable importance and can cause both an expulsion of serum from the cheese and a decrease in cheese moisture content. It was interesting that if cheese $\mathrm{pH}$ had decreased to 4.8 before brining, there was less absorption (or expulsion) of brine (or serum) during the 10-d brining period. This occurred at all temperatures and salt concentrations. 


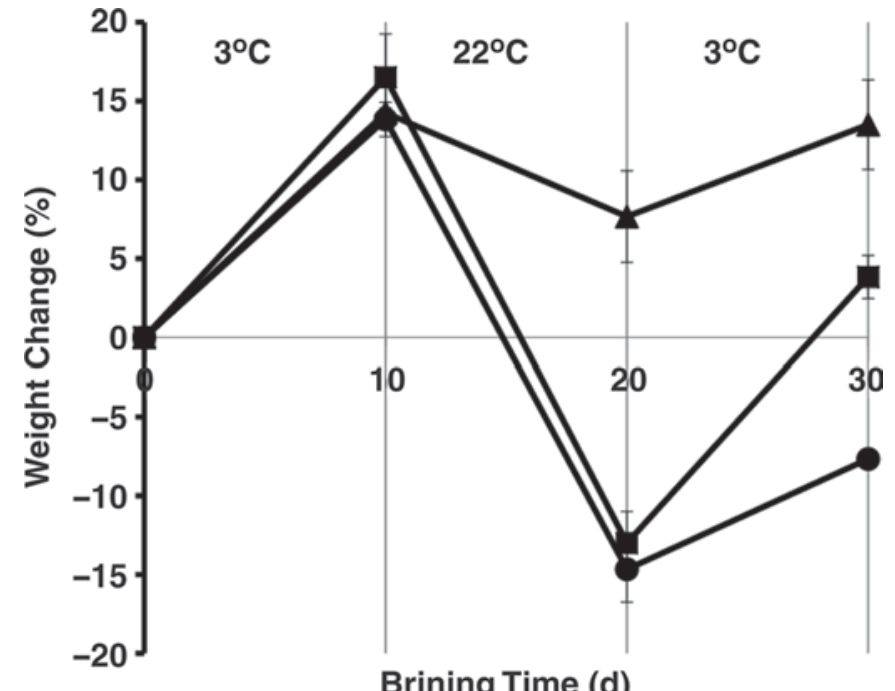

Figure 1. Percentage change in cheese weight $( \pm$ SEM $)$ after brining feta cheese in $6.5(\bullet), 8.0(\mathbf{\square})$, and $9.5 \%(\mathbf{\Delta})$ salt brine solutions for $10 \mathrm{~d}$ at $3^{\circ} \mathrm{C}, 10 \mathrm{~d}$ at $3^{\circ} \mathrm{C}$ plus $10 \mathrm{~d}$ at $22^{\circ} \mathrm{C}$, or $10 \mathrm{~d}$ at $3^{\circ} \mathrm{C}$ plus 10 $\mathrm{d}$ at $22^{\circ} \mathrm{C}$ plus another $10 \mathrm{~d}$ at $3^{\circ} \mathrm{C}$.

For example, increase in cheese moisture content when $\mathrm{pH} 4.92$ cheeses were brined at lower temperatures (3 and $6^{\circ} \mathrm{C}$ ) was about double that for $\mathrm{pH} 4.83$ cheeses. According to Pastorino et al. (2003), as pH is lowered below $\mathrm{pH} 5.0$, the physical properties of cheese change from being dependent on calcium level in the cheese to being dependent on casein insolubility as cheese $\mathrm{pH}$ approaches the isoelectric point of casein. Thus, in the $\mathrm{pH} 4.83$ cheese, decreased solubility of the caseins apparently limits the physical changes that can occur within the protein matrix as the cheese is immersed in brine and cooled.

The overall magnitude of effects of brining temperature $\left(3\right.$ to $\left.22^{\circ} \mathrm{C}\right)$, salt concentration $(6.5$ to $9.5 \%)$ and $\mathrm{pH}$ (4.83 and 4.92) on change in cheese volume were: temperature $\gg$ salt concentration $>\mathrm{pH}$. For cheeses stored in the $6.5 \%$ brine, the crossover from contraction of the cheese to an expansion occurred at $10^{\circ} \mathrm{C}$. For cheeses stored in the 8.0 and $9.5 \%$ brines, it was estimated that at $15^{\circ} \mathrm{C}$ there would be no net change in volume.

\section{Reversibility of Changes During Brining}

When brining was alternated between cold $\left(3^{\circ} \mathrm{C}\right)$ and warm $\left(22^{\circ} \mathrm{C}\right)$ storage conditions, the extent that weight and volume changes were reversible depended on whether they had first been stored cold or warm and, to some extent, the salt concentration of the brine. When cheese was stored cold for $10 \mathrm{~d}$, there was about a $15 \%$ increase in cheese weight in all the cheeses (Fig- ure 1) and a similar change in volume (Figure 2). If such cheeses were then warmed to $22^{\circ} \mathrm{C}$ and stored for $10 \mathrm{~d}$ more, their weight and volume decreased. Cheeses stored in the 6.5 and $8.0 \%$ brines had an overall weight loss (about $-14 \%$ ) that was comparable to just $10 \mathrm{~d}$ of storage in $22^{\circ} \mathrm{C}$ brine (as shown in Table 2 for cheese with a starting $\mathrm{pH}$ of 4.83). However, the weight loss in the cheese stored in $9.5 \%$ brine was much less and the cheese remained heavier than its initial weight. The effect of salt concentration on inhibiting the reversibility of the changes caused by brining cheese is better observed by looking at changes in cheese volume (Figure 2). The higher the salt concentration, the less change in cheese volume occurs during the second 10-d brining period. In $6.5 \%$ brine, the cheese underwent a $13 \%$ increase in volume during the first 10 -d storage at $3{ }^{\circ} \mathrm{C}$; then, after a subsequent $10-\mathrm{d}$ storage at $22^{\circ} \mathrm{C}$, the cheese volume had decreased to $12 \%$ less than its starting size. Cheese stored in $8.0 \%$ brine shrank less, and the cheese stored in $9.5 \%$ brine hardly at all and was still $5 \%$ larger than originally.

When cheese was stored cold for $10 \mathrm{~d}$, then warm for $10 \mathrm{~d}$, and then stored cold for a third 10-d period, it increased in weight and volume compared with cheese that had only the first $20 \mathrm{~d}$ of storage, but did not reach the levels obtained by cheeses that had just the first 10-d of cold storage. Cheeses in each of the 3 brine concentrations increased about $6 \%$ in volume compared with their volume after $20 \mathrm{~d}$. Their overall changes in volume of $-4,+7$, and $+11 \%$ for cheeses in $6.5,8.0$, and $9.5 \%$ brines, respectively, after $30 \mathrm{~d}$ of brining were

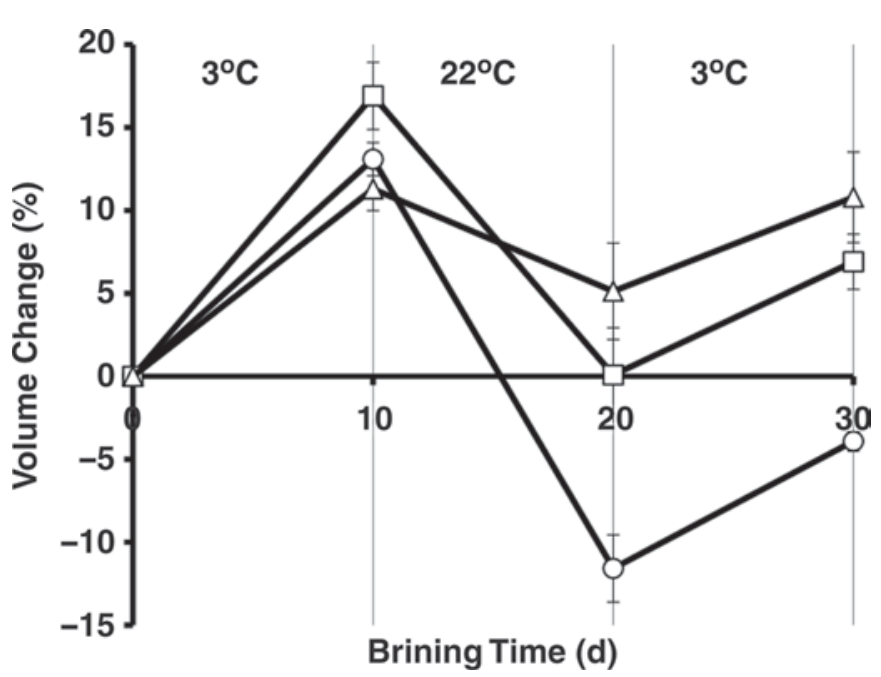

Figure 2. Percentage change in cheese volume ( \pm SEM) after brining feta cheese in $6.5(\bigcirc), 8.0(\square)$, and $9.5 \%(\Delta)$ salt brine solutions for $10 \mathrm{~d}$ at $3^{\circ} \mathrm{C}, 10 \mathrm{~d}$ at $3^{\circ} \mathrm{C}$ plus $10 \mathrm{~d}$ at $22^{\circ} \mathrm{C}$, or $10 \mathrm{~d}$ at $3^{\circ} \mathrm{C}$ plus 10 d at $22^{\circ} \mathrm{C}$ plus another $10 \mathrm{~d}$ at $3^{\circ} \mathrm{C}$. 


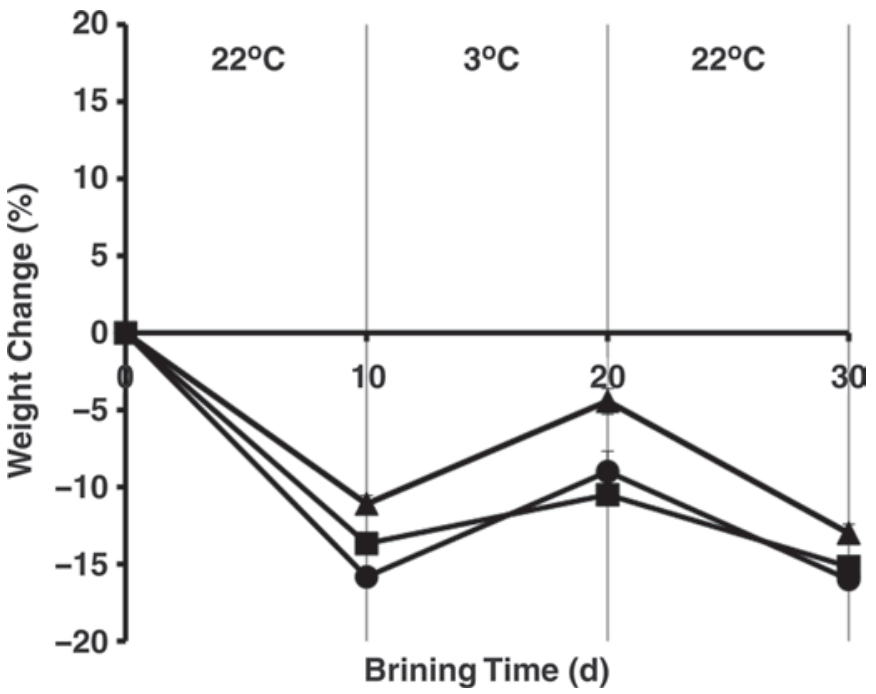

Figure 3. Percentage change in cheese weight $( \pm$ SEM $)$ after brining feta cheese in $6.5(\bullet), 8.0(\mathbf{\square})$, and $9.5 \%(\mathbf{\Delta})$ salt brine solutions for $10 \mathrm{~d}$ at $22^{\circ} \mathrm{C}, 10 \mathrm{~d}$ at $22^{\circ} \mathrm{C}$ plus $10 \mathrm{~d}$ at $3^{\circ} \mathrm{C}$, or $10 \mathrm{~d}$ at $22^{\circ} \mathrm{C}$ plus $10 \mathrm{~d}$ at $3^{\circ} \mathrm{C}$ plus another $10 \mathrm{~d}$ at $22^{\circ} \mathrm{C}$.

dependent on the extent of changes that had occurred during the $10 \mathrm{~d}$ of warm storage.

Therefore, whereas it appears that the expansion of cheese volume that occurs during storage in cold brine can be partly reversed by storage in warm brine, the contraction of the cheese in warm brine is not as reversible. If cheese was first brined at $22^{\circ} \mathrm{C}$ so that cheese volume decreased (along with a concomitant decrease in cheese weight), there was no large increase in weight or volume when the cheese was subsequently stored at $3^{\circ} \mathrm{C}$. Such cheese remained below its original cheese weight (Figure 3) and volume (Figure 4) and well below that after brining for $10 \mathrm{~d}$ at $3^{\circ} \mathrm{C}$ (Figures 1 and 2). Such a scenario of warm brining followed by cold brining is more like the traditional method for making feta cheese in which the cheese blocks are held at 16 to $18^{\circ} \mathrm{C}$ to allow flavor development (Anifantakis and Moatsou, 2006). Brining at warm temperatures induces syneresis of whey that is normally associated with salting (Bines and Holmes, 1994), with the quantity of water lost being about twice the quantity of salt absorbed (Guinee, 2004). Likewise, early brining of cheese (and subsequent cooler temperature of storage) not only produces a more even distribution of salt in the cheese but also higher retention of moisture and higher cheese yield (Bintsis, 2006).

\section{Cheese Microstructure}

The process for making feta cheese has common features with most other rennet-set cheeses such as initial milk coagulation, curd cutting, curd firming stages, block formation, and continued acid development. There are changes in microstructure as curd is converted into cheese as has been shown by Kimber et al. (1975) using transmission electron microscopy and by Oberg et al. (1993) using scanning electron microscopy. The cheese curd consists of a protein matrix with thick strands of protein making up a continuous network with fat globules (either individually or as aggregates) and pools of serum (whey) interspersed throughout. During overnight fermentation of the cheese blocks, further whey syneresis occurs and so the fat and protein components of the cheese matrix become more closely associated with less retained serum.

Differences in microstructure of the cheeses were observed depending on the brining temperature as shown in Figure 5. In these images, the areas corresponding to protein are designated as light green and the fat as orange. The protocol used for preparing the cheese samples for viewing using LSCM included an osmium fixation step that fixes the proteins and the fat in their relative location at the time of fixation. Cheese brined at $3{ }^{\circ} \mathrm{C}$ (Figure $5 \mathrm{a}$ ) had an even distribution of fat droplets throughout the cheese, except for those areas corresponding to curd particle junctions that were devoid of fat. This results from loss of fat from the curd at the time the initial coagulum was cut as previously shown by Paquet and Kalab (1988). The fat droplets had the typical size distribution of fat globules in milk and most appeared spherical.

Some fat droplets appeared as duplets but this was considered an artifact of LSCM. Assignment of pixels in the micrograph as fat is based upon fluorescence of Nile

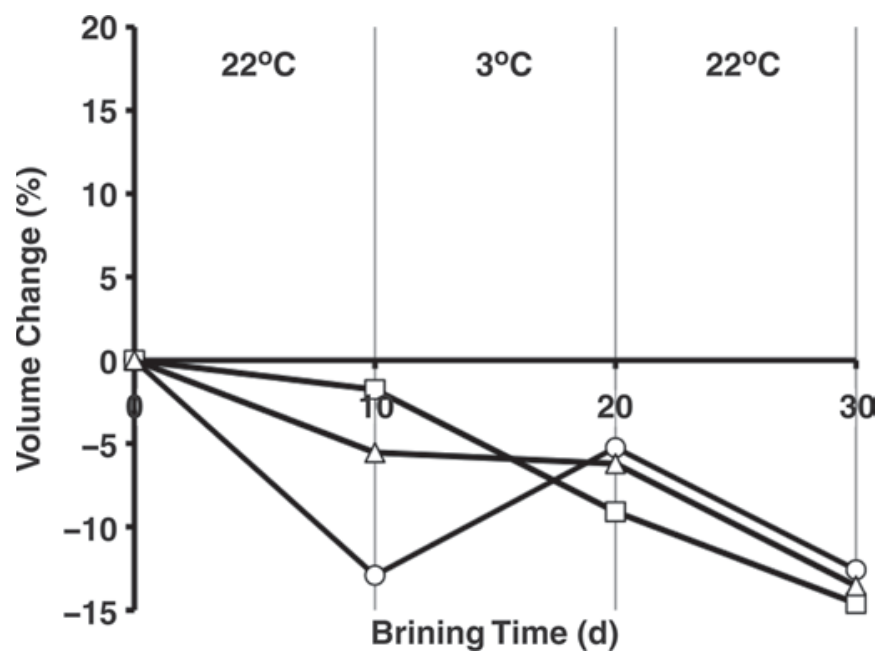

Figure 4. Percentage change in cheese volume $( \pm$ SEM) after brining feta cheese in $6.5(\bigcirc), 8.0(\square)$, and $9.5 \%(\Delta)$ salt brine solutions for $10 \mathrm{~d}$ at $22^{\circ} \mathrm{C}, 10 \mathrm{~d}$ at $22^{\circ} \mathrm{C}$ plus $10 \mathrm{~d}$ at $3^{\circ} \mathrm{C}$, or $10 \mathrm{~d}$ at $22^{\circ} \mathrm{C}$ plus $10 \mathrm{~d}$ at $3^{\circ} \mathrm{C}$ plus another $10 \mathrm{~d}$ at $22^{\circ} \mathrm{C}$. 

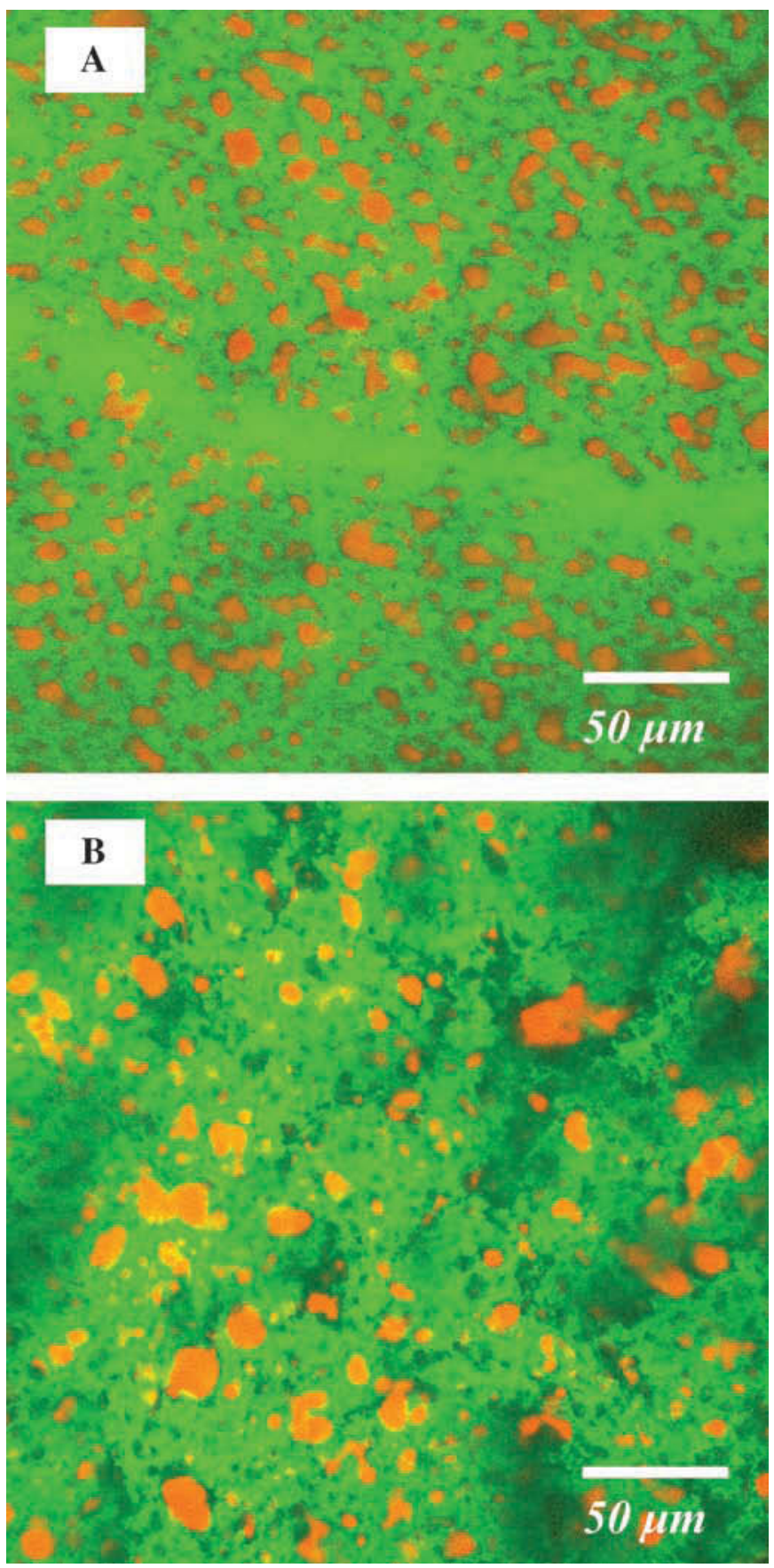

Figure 5. Microstructural images obtained using laser scanning confocal microscopy with fluorescent staining of protein (light green) by fluorescein isothiocyanate and fat (orange) with Nile Red for feta cheese after $10 \mathrm{~d}$ of storage in $8.0 \%$ salt brine at A) $3^{\circ} \mathrm{C}$ or B) $22^{\circ} \mathrm{C}$.

Red when it is excited by the 568-nm band of the laser light. This only occurs when Nile Red is in a lyophilic environment and is much greater in the presence of fat than in the presence of proteins. The light emitted from the Nile Red molecules is then recorded by the LSCM.
Each fluorophore will emit light in all directions (when excited at the appropriate wavelength) and the optics of the microscope captures the cone of light directed toward the aperture of the objective lens as the LSCM scans across the field of view of the sample. The observed size of each group of emitting fluorophores, such as fat droplets with their attached Nile Red molecules, will appear larger than their actual size. Taking this into account, the observed duplets would probably be individual fat globules that are adjacent to each other but have not coalesced. Some fat droplets do appear to have lost the spherical shape of native milk fat globules but there is little evidence of large pools of free coalesced fat within the cheese microstructure after brining at $3{ }^{\circ} \mathrm{C}$.

Cheese that had been brined at $22^{\circ} \mathrm{C}$ was different from that at $3{ }^{\circ} \mathrm{C}$ in both the extent to which the protein matrix occupied the cheese microstructure and the arrangement of fat (Figure 5b). Rather than there being a continuous protein matrix (as observed in cheese brined at $3^{\circ} \mathrm{C}$ ), interspersed with the protein matrix (light green) were numerous small and large areas that were relatively devoid of protein (dark green). These areas represent serum droplets and pools and frequently appear around the fat droplets. Such a change in microstructure as a function of temperature has previously been observed in nonfat cheese (Pastorino et al., $2002)$. Under cool conditions $\left(10^{\circ} \mathrm{C}\right)$, nonfat cheese had a homogeneous protein matrix without any free serum, as we observed for cheese brined at $3^{\circ} \mathrm{C}$. In contrast, nonfat cheese at $50^{\circ} \mathrm{C}$ had large pools of free water that Pastorino et al. (2002) concluded was a result of contraction of the protein matrix under the influence of increased protein-protein hydrophobic interactions at the higher temperature and an internal micro-syneresis of serum from within the protein matrix.

These microstructural changes induced by a change in temperature do not always result in an observable macroscopic change such as the changes in weight or volume that occurred in this experiment. For nonfat cheese, a change in opacity can be observed with the cheese being translucent at cold temperatures and becoming opaque as it is heated (Paulson et al., 1998). This change in opacity is less apparent in full-fat cheeses because the fat globules are the major light scattering centers. A block of cheese that is vacuum packaged, however, cannot increase in weight, although a loss of weight can occur if there is any syneresis during storage. McMahon et al. (1999) have shown that during cold storage of Mozzarella cheese, the water contained in serum pockets in the cheese after manufacture is absorbed into the protein matrix. Concomitantly, the protein matrix expands and eventually occupies all 
the space except for that occupied by the fat globules. This corresponds to the microstructure observed in feta cheese when brined at $3^{\circ} \mathrm{C}$ (Figure 5a).

As well as the contracted appearance of the protein matrix after brining at $22^{\circ} \mathrm{C}$, the fat also appeared less evenly dispersed. Some fat was present as individual droplets dispersed throughout the protein matrix, but there were also larger pools of coalesced fat droplets. These seemed associated with the serum pockets, and possibly occur as the protein matrix contracts away from the fat allowing any fat droplets with mechanically damaged fat globule membranes to coalesce.

\section{CONCLUSIONS}

During brining of feta cheese there is a change in cheese weight that is influenced by temperature, salt concentration of the brine, and initial cheese composition. Absorption of salt from brine accounted for some of the weight change, but this can be overshadowed by changes in cheese volume. All cheeses absorbed salt, and reached a moisture S/M level based on the amount of salt in the brine and the total moisture present in the brine and cheese, which for equal starting weights of cheese and brine was $4.6,5.7$, and $6.7 \mathrm{~g} / 100 \mathrm{~g}$ for the $6.5,8.0$, and $9.5 \%$ brines, respectively. Cheeses brined at $3{ }^{\circ} \mathrm{C}$ increased in moisture content, whereas those brined at $22^{\circ} \mathrm{C}$ decreased in moisture content with intermediate changes occurring at 6 and $10^{\circ} \mathrm{C}$.

Fermenting cheese to a lower $\mathrm{pH}$ (4.83 vs. 4.92) before brining partially prevented moisture uptake by the cheese such that when brined at $6^{\circ} \mathrm{C}$, the cheeses had mean changes in moisture content of -0.8 and +4.1 $\mathrm{g} / 100 \mathrm{~g}$, respectively. This trend would be expected to continue if initial $\mathrm{pH}$ of cheese dropped below $\mathrm{pH}$ 4.83. Cheese $\mathrm{pH}$ decreased during brining based on salt concentration and temperature, with no change occurring at $3^{\circ} \mathrm{C}$ in $9.5 \%$ brine and $\mathrm{pH}$ dropping to $\mathrm{pH} 4.15$ \pm 0.03 in $6.5 \%$ brine at $22^{\circ} \mathrm{C}$.

Volume changes were mainly dependent on temperature with only slight increases in cheese volume as brine concentration increased At $3^{\circ} \mathrm{C}$, the cheeses expanded with increases in volume of 11 to $28 \%$ and had a cheese microstructure consisting of only a well-hydrated protein matrix containing dispersed fat globules. In contrast, when brine at $22^{\circ} \mathrm{C}$, the cheese shrank from 1 to $17 \%$ as a consequence of a contraction of the protein matrix presumably because of increased protein-protein hydrophobic associations. Such cheeses had numerous serum pockets interrupting the protein matrix and increased presence of coalesced fat droplets.

These changes in cheese during brining are only partially reversible when the temperature is changed. In general, the cheeses will expand when the temperature is lowered, but initial exposure to $22^{\circ} \mathrm{C}$ for $10 \mathrm{~d}$ inhibited expansion of the protein matrix when temperature was subsequently lowered to $3^{\circ} \mathrm{C}$, and the cheeses remained below their original weight and volume. Thus, temperature history as well as cheese $\mathrm{pH}$ before brining, brining temperature, and brine salt concentration all affect yield of feta cheese obtained after brining.

\section{ACKNOWLEDGMENTS}

The authors thank Nidhi Gharg (Utah State University, Logan) for performing statistical analysis. This research was supported by the Utah Agricultural Experiment Station, Utah State University, and approved as journal paper No. 8028 .

\section{REFERENCES}

Abd El-Salam, M. H., and E. Alichanidis. 2004. Cheese varieties ripened in brine. Pages 227-240 in Cheese Chemistry, Physics and Microbiology, Vol. 2. P. F. Fox, P. L. H. McSweeney, T. M. Cogan, and T. P. Guinee, ed. Elsevier Academic Press, London, UK.

Alichanidis, E., A. Polychroniadou, N. Tzanetakis, and A. Vafopoulou. 1981. Teleme cheese from deep-frozen curd. J. Dairy Sci. 64:732739.

Anifantakis, E. M., and G. Moatsou. 2006. Feta and other Balkan cheeses. Pages 43-76 in Brined Cheeses, A. Tamime, ed., Blackwell Publishing, Oxford, UK.

European Union. 2002. European Union Commission Regulation No. 1829-Amending to the Annex to Regulation (EC) No. 1107/96 with regard to the name "Feta". Off. J. L 277:10-14.

Chr. Hansen. 2009. Chr. Hansen launches two new culture blends for feta cheese. Chr. Hansen A/S. http://www.chr-hansen.com/press/ news/show_news/chr-hansen-launches-two-new-culture-blendsfor-feta-cheese.html Accessed Jan 12, 2009.

Bines, V., and D. Holmes. 1994. Brine salting of cheese. Dairy Indust. Int. 59:33-38.

Bintsis, T. 2006. Quality of Brine. Pages 264-301 in Brined Cheeses. A. Tamime, ed., Blackwell Publishing, Oxford, UK.

Geurts, T. J., P. Walstra, and H. Mulder. 1972. Brine composition and the prevention of the defect 'soft rind' in cheese. Neth. Milk Dairy J. 26:168-179.

Guinee, T. P. 2004. Salting and the role of salt in cheese. Int. J. Dairy Technol. 57:99-109.

Guinee, T. P., and P. F. Fox. 2004. Salt in Cheese: Physical, Chemical and Biological Aspects. Pages 207-259 in Cheese Chemistry, Physics and Microbiology, Vol. 1. General Aspects. 3rd ed. P. F. Fox, P. L. H. McSweeney, T. M. Cogan, and T. P. Guinee, ed. Elsevier Academic Press, Oxford, UK.

Kimber, A. M., B. E. Brooker, D. G. Hobbs, and J. H. Prentice. 1975. Electron microscope studies of the development of structure in Cheddar cheese. J. Dairy Res. 41:389-396.

McMahon, D. J., R. L. Fife, and C. J. Oberg. 1999. Water partitioning in Mozzarella cheese and its relationship to cheese meltability. J. Dairy Sci. 82:1361-1369.

McManus, W. R., K. M. Larsen, and D. J. McMahon. 2009 Identification of starch in milk protein gels using confocal microscopy. Microscopy Today 17(4):68.

Melilli, C., D. M. Barbano, G. Licitra, G. Portelli, G. Di Rosa, and S. Carpino. 2003. Influence of the temperature of salt brine on salt uptake by Ragusano cheese. J. Dairy Sci. 86:2799-2812.

Metzger, L. E., D. M. Barbano, M. A. Rudan, P. S. Kindstedt, and M. R. Guo. 2000. Whiteness change during heating and cooling of Mozzarella cheese. J. Dairy Sci. 83:1-10.

Oberg, C. J., W. McManus, and D. J. McMahon. 1993. Microstructure of Mozzarella cheese during manufacture. Food Struct. 12:251258. 
Pappas, C. P., E. Kondyli, L. P. Voutsinas, and H. Mallatou. 1996. Effects of salting method and storage time on the composition and quality of Feta cheese. J. Soc. Dairy Technol. 49:113-118.

Paquet, A., and M. Kalab. 1988. Amino acid composition and structure of cheese baked as a pizza ingredient in conventional and microwave ovens. Food Microstruct. 7:93-103.

Pastorino, A. J., R. I. Dave, C. J. Oberg, and D. J. McMahon. 2002. Temperature effect on structure-opacity relationships of nonfat Mozzarella cheese. J. Dairy Sci. 85:2106-2113.

Pastorino, A. J., C. L. Hansen, and D. J. McMahon. 2003. Effect of pH on the chemical composition and structure-function relationships of cheese. J. Dairy Sci. 86:2751-2760.

Paulson, B. M., D. J. McMahon, and C. J. Oberg. 1998. Influence of salt on appearance, functionality, and protein arrangements in nonfat Mozzarella cheese. J. Dairy Sci. 81:2053-2064.
Prasad, N., and V. B. Alvarez. 1999. Effect of salt and chymosin on the physicochemical properties of Feta cheese during ripening. J. Dairy Sci. 82:1061-1067.

Richardson, G. H., ed. 1985. Page 351 in Standard Methods for the Examination of Dairy Products. 15th ed. Am. Publ. Health Assoc., Washington, DC.

Tamime, A. Y., D. G. Dalgleish, and W. Banks. 1996. Introduction. Pages 11-48 in Feta and Related Cheeses, R. K. Robinson and A. Y. Tamime, ed. Woodhead Publishing Ltd., Cambridge, UK.

Turhan, M., and G. Kaletunç. 1992. Modeling of salt diffusion in white cheese during long-term ripening. J. Food Sci. 57:1082-1085. 